\title{
Triethylammonium salt of dimethyl diphenyldithiophosphates: Single crystal $X$-ray and DFT analysis
}

\author{
SANDEEP KUMAR $^{\mathrm{a}}$, RUCHI KHAJURIA ${ }^{\mathrm{a}}$, MANDEEP KOUR ${ }^{\mathrm{a}}$, RAKESH KUMAR $^{\mathrm{b}}$, \\ LOVE KARAN RANA $^{\mathrm{c}}$, GEETA HUNDAL ${ }^{\mathrm{c}}$, VIVEK K GUPTA ${ }^{\mathrm{d}}$, RAJNI KANT ${ }^{\mathrm{d}}$ and \\ SUSHIL K PANDEY ${ }^{\mathrm{a}, *}$ \\ ${ }^{\text {a}}$ Department of Chemistry, University of Jammu, Jammu 180 006, India \\ ${ }^{b}$ Department of Chemistry, DAV University, Jalandhar 144 012, India \\ ${ }^{c}$ Department of Chemistry, Guru Nanak Dev University, Amritsar 143 005, India \\ ${ }^{\mathrm{d} X-r a y ~ C r y s t a l l o g r a p h i c ~ L a b o r a t o r y, ~ D e p a r t m e n t ~ o f ~ P h y s i c s ~ a n d ~ E l e c t r o n i c s, ~}$ \\ University of Jammu, Jammu 180 006, India \\ e-mail: kpsushil@rediffmail.com
}

MS received 3 December 2015; accepted 29 March 2016

\begin{abstract}
The present work demonstrates the single crystal X-ray and DFT analysis of $\left[\left\{\left(2,4-\mathrm{CH}_{3}\right)_{2} \mathrm{C}_{6} \mathrm{H}_{3} \mathrm{O}\right\}_{2}\right.$ $\left.\mathrm{PS}_{2} \mathrm{HNEt}_{3}\right](\mathbf{1})$ and $\left[\left\{\left(3,4-\mathrm{CH}_{3}\right)_{2} \mathrm{C}_{6} \mathrm{H}_{3} \mathrm{O}\right\}_{2} \mathrm{PS}_{2} \mathrm{HNEt}_{3}\right](2)$ along with computational analysis of $\left[\left\{\left(3,5-\mathrm{CH}_{3}\right)_{2}\right.\right.$ $\mathrm{C}_{6} \mathrm{H}_{3} \mathrm{O}_{2} \mathrm{PS}_{2} \mathrm{HNEt}_{3}$ ] (3) by using density functional theory (DFT) in its hybrid form B3LYP method. Compounds $\mathbf{1}$ and $\mathbf{2}$ crystallize in the orthorhombic space group $P b c a$ and triclinic space group $P 1$, respectively and their $\mathrm{X}$-ray analysis reveals that phosphorus atom is coordinated to the two $\mathrm{S}$ and two $\mathrm{O}$ atoms to form tetrahedral geometry. The structure is stabilized by cation-anion $\mathrm{N}-\mathrm{H} \cdots \mathrm{S}$ hydrogen bonded interactions. The structural parameters, vibrational bands and energy gaps of frontier orbitals (HOMO-LUMO) have been calculated. The calculated geometric and spectral results matched the experimental data with good agreement. Theoretically calculated frontier molecular orbitals (HOMO-LUMO) and their energies suggest that charge transfer occurs within the compounds.
\end{abstract}

Keywords. Diphenyldithiophosphate; DFT; Single crystal X-ray; IR; HOMO-LUMO

\section{Introduction}

$O, O^{\prime}$-Dialkyl- and alkylenedithiophosphates are extensively studied in which the ligands exhibited remarkable diversities in organic derivatives and their coordination pattern with the metals. ${ }^{1-6}$ These soft donor ligands are versatile ligands which show both chelating bidentate ${ }^{7,8}$ and less common monodentate linkage. ${ }^{9,10}$ The importance of metal dithiophosphates in petroleum industry as an oil additive ${ }^{11,12}$ and in agriculture ${ }^{13}$ as pesticides are well known. Recently, synthesis and characterization of ditolyldithiophosphates added a new extension in the area of dithiophosphate chemistry. ${ }^{14,15}$ These new ditolyldithiophosphate ligands appear to be potential chelating ligands to the metals, metalloids and nonmetals akin to the dialkyl- and alkylenedithiophosphate ligands. Some metal complexes with the ditolyl/dibenzyl dithiophosphate ligands have also been reported. ${ }^{16-24}$ In our laboratory, we were successful in isolating a number of triethylammonium salt of disubstituted diphenyldithiophosphates ${ }^{25}$ and their metal derivatives. ${ }^{26}$ The

\footnotetext{
*For correspondence
}

literature survey reveals only a few reports of theoretical calculations on the structural and vibrational properties of dithiophosphates. ${ }^{27,28}$ To the best of our knowledge, reports on theoretical calculations of ditolyl/ diphenyldithiophosphates have not been described so far. In order to comprehend and understand the experimental studies and to provide better insight into molecular parameters and vibrational spectra of the compounds, a comparison of computed structural and spectroscopic data with the previously reported experimental (crystallographic and spectroscopic) results has been investigated for the title compounds. The present work describes the crystal structures and DFT analyses of previously reported triethylammonium salt of disubstituted diphenyldithiophosphates. ${ }^{25}$

\section{Experimental}

\subsection{Crystallography data collection and refinement}

Crystallization of compounds $\left[\left\{\left(2,4-\mathrm{CH}_{3}\right)_{2} \mathrm{C}_{6} \mathrm{H}_{3} \mathrm{O}\right\}\right.$ $\left.{ }_{2} \mathrm{PS}_{2} \mathrm{HNEt}_{3}\right](\mathbf{1})$ and $\left[\left\{\left(3,4-\mathrm{CH}_{3}\right)_{2} \mathrm{C}_{6} \mathrm{H}_{3} \mathrm{O}\right\}_{2} \mathrm{PS}_{2} \mathrm{HNEt}_{3}\right]$ (2) was executed by very slow evaporation of their 
saturated solution in chloroform/n-hexane mixture (3:1) at room temperature which yielded suitable single crystals for X-ray analysis. X-ray data of compound $\mathbf{1}$ was collected on a Bruker Apex-II CCD diffractometer (Department of Chemistry, Guru Nanak Dev University, Amritsar) using Mo K $\alpha(\lambda=0.71069 \AA)$ at room temperature. The data were processed by SAINT correcting for Lorentz and polarization effects. An empirical absorption correction was applied using SADABS. ${ }^{29}$ The solution was obtained by direct methods, using SIR- $92^{30}$ and refined by full-matrix least squares refinement methods ${ }^{31}$ based on $\mathrm{F}^{2}$, using SHELX-97. All non-hydrogen atoms were refined anisotropically. All calculations were performed using Wingx package. ${ }^{32}$ X-ray data of compound $\mathbf{2}$ was collected on an X' caliburOxford Diffraction single crystal diffractometer (Department of Physics and Electronics, University of Jammu, Jammu) with CCD area-detector (graphitemonochromator, Mo-K $\alpha$ radiations, $\lambda=0.71073 \AA$ A). Data were corrected for Lorentz, polarization and absorption factors. The structures were solved by direct methods using SHELXS97. ${ }^{31}$ All non-H atoms were located in the best E-map. Full-matrix least-squares refinement was carried out using SHELXL97. ${ }^{31}$ The geometry of the molecule was calculated using WinGX, ${ }^{33}$ PARST $^{33}$ and PLATON. ${ }^{34}$ Atomic scattering factors were taken from the International Tables for X-ray Crystallography (1992, Vol. C, Tables 4.2.6.8 and 6.1.1.4). Molecular drawings were obtained using DIAMOND version 2.1. ${ }^{35}$ Crystallographic data, details of the data collection, structure solution and refinements are listed in table 1 .

\subsection{Computational details}

The quantum chemical calculations (DFT calculations) giving molecular geometries of minimum energies, molecular orbitals (HOMO-LUMO) and vibrational spectra were performed using the Gaussian 03 package. ${ }^{36}$ Molecular orbitals are visualized using "Gauss view". The method used was Becke's three-parameter hybridexchange functional, the nonlocal correlation provided by the Lee, Yang and Parr expression, and the Vosko, Wilk, and Nuair 1980 local correlation functional (III) (B3LYP). ${ }^{37}$ The 6-31G*(d,p) basis set was used for $\mathrm{C}$, $\mathrm{N}, \mathrm{O}, \mathrm{P}$ and $\mathrm{S}$ atoms. The input coordinates are obtained from the crystal structure data. The structural parameters were adjusted until an optimal agreement between calculated and experimental structure obtained throughout the entire range of available structures. Structural parameters obtained from the already reported crystal structures $^{25}$ were compared with those of optimized geometries. DFT study of number of metal complexes and compounds have been carried out with this DFT/ B3LYP/6-31G*/LANL2DYZ method and found to be suitable for this study and to produce the experimental results. ${ }^{38}$

Table 1. Summary of the crystal structure, data collection and structure refinement parameters for compounds $\mathbf{1}$ and $\mathbf{2}$.

\begin{tabular}{lll}
\hline Compound & $\mathbf{1}$ & $\mathbf{2}$ \\
\hline Chemical formula & $\mathrm{C}_{16} \mathrm{H}_{18} \mathrm{O}_{2} \mathrm{PS}_{2} \cdot \mathrm{C}_{6} \mathrm{H}_{16} \mathrm{~N}$ & $\mathrm{C}_{16} \mathrm{H}_{18} \mathrm{O}_{2} \mathrm{PS}_{2} \cdot \mathrm{C}_{6} \mathrm{H}_{16} \mathrm{~N}$ \\
$M_{\mathrm{r}}$ & 439.61 & 439.61 \\
Crystal system, space group & Orthorhombic, $\mathrm{Pbca}$ & Triclinic, $P 1$ \\
Temperature $(\mathrm{K})$ & 100 & 296 \\
$a, b, c(\AA)$ & $9.1400(4), 15.5853(8), 32.8880(15)$ & $7.5104(8), 7.8179(8), 10.5067(11)$ \\
$\alpha, \beta, \gamma\left({ }^{\circ}\right)$ & $90.00,90.00,90.00$ & $86.392(9), 85.285(9), 87.164(8)$ \\
$V\left(\AA^{3}\right)$ & $4684.9(4)$ & $612.99(11)$ \\
$Z$ & 8 & 1 \\
Radiation type & Mo $K \alpha$ & Mo $K \alpha$ \\
$\mu\left(\mathrm{mm}^{-1}\right)$ & 0.31 & 0.30 \\
Crystal size $(\mathrm{mm})$ & $0.11 \times 0.08 \times 0.06$ & $0.30 \times 0.20 \times 0.20$ \\
Diffractometer & $\mathrm{Bruker} A P E X-\mathrm{II} \mathrm{CCD}$ diffractometer & Xcalibur, Sapphire3 diffractometer \\
Absorption correction & Multi-scan & Multi-scan \\
$T_{\min }, T_{\max }$ & $0.678,0.747$ & $0.904,1.000$ \\
No. of measured, independent and & $39777,9788,6551$ & $4318,2404,2041$ \\
observed $[I>2 \sigma(I)]$ reflections & & \\
$R_{\text {int }}$ & 0.048 & 0.032 \\
$(\text { sin } \theta / \lambda)_{\max }\left(\AA^{-1}\right)$ & 0.797 & 0.617 \\
$R\left[F^{2}>2 \sigma\left(F^{2}\right)\right], w R\left(F^{2}\right), S$ & $0.047,0.126,0.96$ & $0.056,0.154,1.05$ \\
No. of reflections & 9788 & 2404 \\
No. of parameters & 256 & 261 \\
No. of restraints & 1 & 4 \\
$\Delta \rho_{\max }, \Delta \rho_{\min }\left(\mathrm{e} \AA^{-3}\right)$ & $0.49,-0.35$ & $0.66-0.28$ \\
\hline & &
\end{tabular}




\section{Results and Discussion}

\subsection{Crystal and molecular structures of compounds $\mathbf{1}$ and 2}

The compounds $\mathbf{1}$ and $\mathbf{2}$ were crystallized in the orthorhombic space group $P b c a$ and triclinic space group $P 1$, respectively. Selected bond distances and bond angles for the compounds $\mathbf{1}$ and $\mathbf{2}$ are listed in tables 2 and 3.

A distorted tetrahedral environment around phosphorus can be clearly seen with two sulfurs and two oxygens bonded to phosphorus (figure 1). The compounds 1 and 2 consist of triethylammonium and dithiophosphate moiety which are connected through $\mathrm{N}-\mathrm{H} \cdots \mathrm{S}$ (table 4) intermolecular hydrogen bond. The $\mathrm{N}-\mathrm{S}$ bond distances for compounds $\mathbf{1}$ and $\mathbf{2}$ are 3.185(1) and 3.337(5) $\AA$ which compare well with the value of (3.248(6) $\AA$ ) reported ${ }^{39}$ for $\left[\mathrm{Et}_{3} \mathrm{NH}\right]^{+}\left[\left(\mathrm{OCH}_{2} \mathrm{CMe}_{2} \mathrm{CH}_{2} \mathrm{O}\right) \mathrm{PS}_{2}\right]^{-}$. The values for the remaining hydrogen bonding parameters in compounds $\mathbf{1}$ and $\mathbf{2}$ of $\mathrm{H} \cdots \mathrm{S}$ are 2.33 and 2.57

Table 2. Selected experimental and calculated bond lengths (A) and angles $\left(^{\circ}\right)$ for compound $\mathbf{1}$.

\begin{tabular}{llll}
\hline $\begin{array}{l}\text { Bond lengths/ } \\
\text { Bond angles }\end{array}$ & Experimental & Calculated & Deviation \\
\hline $\mathrm{N} 1-\mathrm{H} 1$ & $0.881(13)$ & 0.950 & -0.069 \\
$\mathrm{O} 1-\mathrm{P} 1$ & $1.6279(10)$ & 1.678 & -0.050 \\
$\mathrm{O} 2-\mathrm{P} 1$ & $1.6140(10)$ & 1.661 & -0.047 \\
$\mathrm{P} 1-\mathrm{S} 1$ & $1.9413(5)$ & 2.014 & -0.073 \\
$\mathrm{P} 1-\mathrm{S} 2$ & $1.9779(5)$ & 1.989 & -0.012 \\
$\mathrm{O} 2-\mathrm{P} 1-\mathrm{S} 2$ & $110.17(4)$ & 109.16 & 1.01 \\
$\mathrm{O} 1-\mathrm{P} 1-\mathrm{S} 2$ & $108.91(4)$ & 107.78 & 1.13 \\
$\mathrm{~S} 1-\mathrm{P} 1-\mathrm{S} 2$ & $118.46(2)$ & 118.97 & -0.51 \\
$\mathrm{O} 2-\mathrm{P} 1-\mathrm{O} 1$ & $96.76(5)$ & 96.05 & 0.71 \\
$\mathrm{O} 2-\mathrm{P} 1-\mathrm{S} 1$ & $108.06(4)$ & 107.78 & 0.28 \\
$\mathrm{O} 1-\mathrm{P} 1-\mathrm{S} 1$ & $112.30(4)$ & 111.63 & 0.67 \\
\hline
\end{tabular}

Table 3. Selected experimental and calculated bond lengths

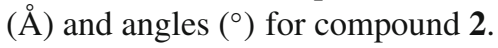

\begin{tabular}{llll}
\hline $\begin{array}{l}\text { Bond lengths/ } \\
\text { Bond angles }\end{array}$ & Experimental & Calculated & Deviation \\
\hline N1-H1A & $0.87(5)$ & 0.717 & 0.153 \\
O1-P1 & $1.621(4)$ & 1.607 & 0.014 \\
O2-P1 & $1.606(4)$ & 1.622 & -0.016 \\
P1-S2 & $1.9440(18)$ & 1.961 & -0.017 \\
P1-S1 & $1.9626(18)$ & 1.944 & 0.0186 \\
O2-P1-S1 & $104.79(17)$ & 111.82 & -7.03 \\
O1-P1-S1 & $110.37(16)$ & 113.82 & -3.45 \\
S2-P1-S1 & $117.94(9)$ & 117.94 & 0 \\
O2-P1-O1 & $95.7(2)$ & 95.67 & 0.03 \\
O2-P1-S2 & $113.85(17)$ & 110.38 & 3.47 \\
O1-P1-S2 & $111.82(16)$ & 104.78 & 7.04 \\
\hline
\end{tabular}

$\AA$ and $\mathrm{N}-\mathrm{H} \cdots \mathrm{S}$ are $162^{\circ}$ and $149^{\circ}$, respectively, compared to $\left(2.44 \AA\right.$ and $\left.160^{\circ}\right) .{ }^{39}$ It is clear that the sulfur atoms, involved in hydrogen bonding, have the longer P-S bonds (1.9779(7) $\AA$ and 1.9626(18) $\AA$ ) in compounds 1 and 2 whereas the sulfur atoms not involved in hydrogen bonding have shorter the S-P bonds lengths (1.9413(5) and 1.9440(18) $\AA$ ). These bond lengths are longer than the terminal $\mathrm{P}=\mathrm{S}$ bonds observed in $\mathrm{HS}_{2} \mathrm{POCMe}_{2} \mathrm{CMe}_{2} \mathrm{O}$ and $\mathrm{HS}_{2} \mathrm{POCH}_{2} \mathrm{CMe}_{2} \mathrm{CH}_{2} \mathrm{O}$ (1.923(2) and 1.908(2) A), ${ }^{40}$ respectively, but shorter than those of $\mathrm{K}_{2}^{+}\left[(\mathrm{MeO}) \mathrm{OPS}_{2}\right]^{-} . \mathrm{H}_{2} \mathrm{O}$ (2.007(6) and 2.011(5) $\AA),{ }^{41}$ which is reflecting their partial double bond character. The average $\mathrm{P}-\mathrm{O}$ bond lengths in
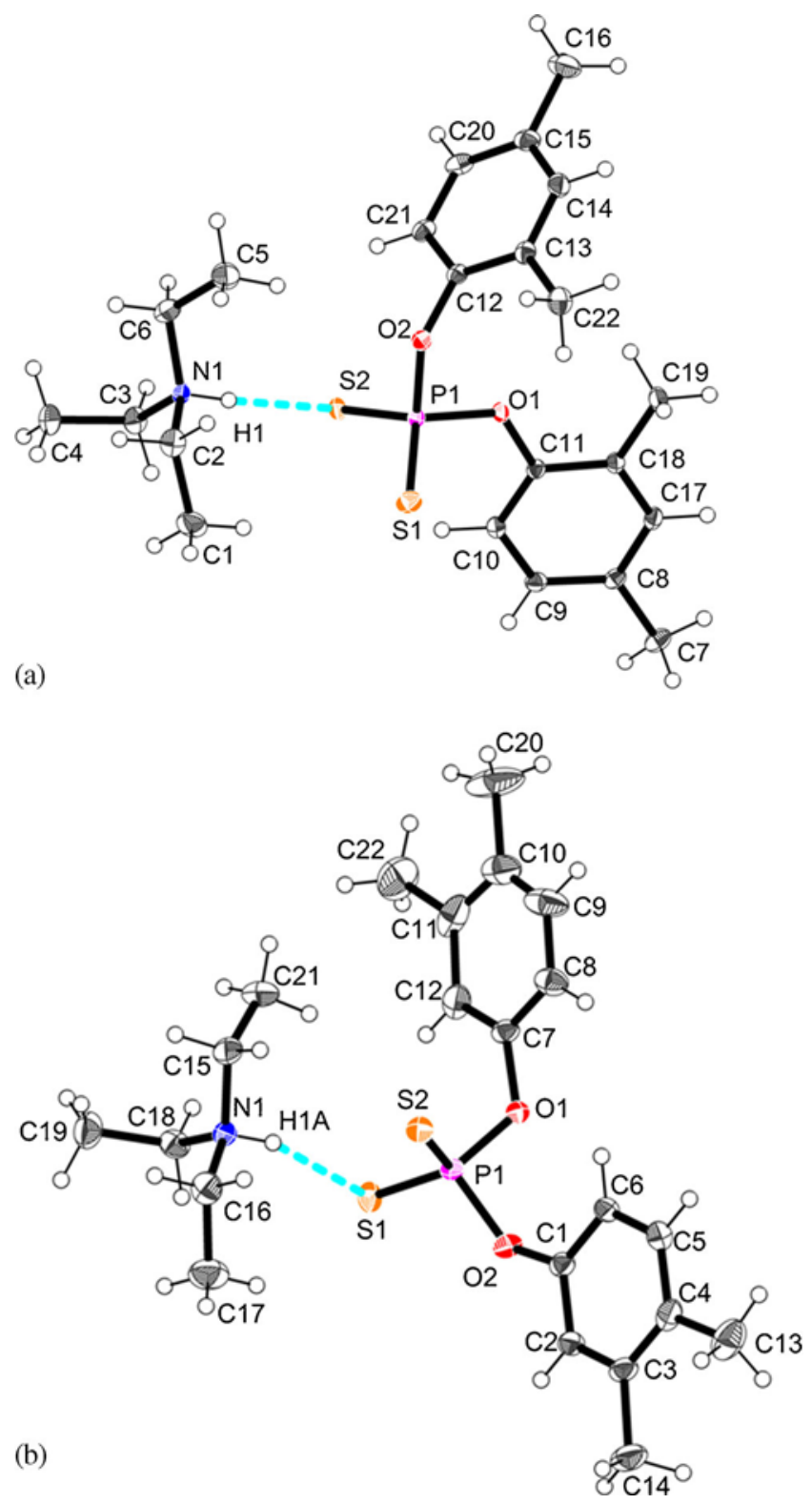

Figure 1. Molecular structure of (a) $\left[\left\{\left(2,4-\mathrm{CH}_{3}\right)_{2} \mathrm{C}_{6} \mathrm{H}_{3} \mathrm{O}\right\}_{2}\right.$ $\left.\mathrm{PS}_{2} \mathrm{HNEt}_{3}\right]$ (1); (b) $\left[\left\{\left(3,4-\mathrm{CH}_{3}\right)_{2} \mathrm{C}_{6} \mathrm{H}_{3} \mathrm{O}\right\}_{2} \mathrm{PS}_{2} \mathrm{HNEt}_{3}\right]$ (2) with displacement ellipsoids drawn at $40 \%$ probability level. 
Table 4. Selected hydrogen bonding interactions for compounds $\mathbf{1}$ and $\mathbf{2}$.

\begin{tabular}{lcccc}
\hline Compound & $\mathrm{D}-\mathrm{H} \cdots \mathrm{A}$ & $\mathrm{H} \cdots \mathrm{A}(\AA)$ & $\mathrm{D} \cdots \mathrm{A}(\AA)$ & $\mathrm{D}-\mathrm{H} \cdots \mathrm{A}\left({ }^{\circ}\right)$ \\
\hline $\mathbf{1}$ & $\mathrm{N} 1-\mathrm{H} 1 \cdots \mathrm{S} 2^{1}$ & $2.334(16)$ & $3.185(1)$ & 162.54 \\
$\mathbf{2}$ & $\mathrm{N} 1-\mathrm{H} 1 \mathrm{~A} \cdots \mathrm{S} 1$ & $2.57(4)$ & $3.337(5)$ & 149 \\
\hline
\end{tabular}

Symmetry code: (i) $\mathrm{x}+1,+\mathrm{y},+\mathrm{z}$

compounds 1 and 2 are 1.620(10) and 1.613(4) $\AA$ which are similar to those of $\left[\mathrm{Et}_{3} \mathrm{NH}\right]^{+}\left[\left(2-\mathrm{MeC}_{6} \mathrm{H}_{4} \mathrm{O}\right)_{2} \mathrm{PS}_{2}\right]^{-}$ $(1.622(2) \AA) .{ }^{42}$ However, these bonds are slightly longer than that found in the free acids $\mathrm{HS}_{2} \mathrm{POCMe}_{2}$ $\mathrm{CMe}_{2} \mathrm{O}(1.5915(3) \AA)$ and $\mathrm{HS}_{2} \mathrm{POCH}_{2} \mathrm{CMe}_{2} \mathrm{CH}_{2} \mathrm{O}$ (1.5825(3) А). ${ }^{40}$

The S-P-S bond angles for the compounds $\mathbf{1}$ and $\mathbf{2}$ are of $118.46(2)^{\circ}$ and $117.94(9)^{\circ}$ are akin to those in $\left[\mathrm{Et}_{3} \mathrm{NH}\right]^{+}\left[\left(2-\mathrm{MeC}_{6} \mathrm{H}_{4} \mathrm{O}\right)_{2} \mathrm{PS}_{2}\right]^{-}\left(118.62(4)^{\circ}\right)^{42}$ but smaller than in $\left[\mathrm{Et}_{3} \mathrm{NH}\right]^{+}\left[\mathrm{CH}_{2}\left\{6-\mathrm{t}-\mathrm{Bu}-4-\mathrm{Me}-\mathrm{C}_{6} \mathrm{H}_{4} \mathrm{O}\right\}_{2}\right.$ $\mathrm{P}(\mathrm{S})(\mathrm{S})]^{-}\left(120.49(8)^{\circ}\right)^{39}$ while larger compared to the ligands $\mathrm{HS}_{2} \mathrm{POCMe}_{2} \mathrm{CMe}_{2} \mathrm{O}\left(112.78(8)^{\circ}\right), \mathrm{HS}_{2} \mathrm{POCH}_{2}$ $\mathrm{CMe}_{2} \mathrm{CH}_{2} \mathrm{O}\left(115.64(8)^{\circ}\right)^{40}$ and $\mathrm{K}_{2}^{+}\left[(\mathrm{MeO}) \mathrm{OPS}_{2}\right]^{-} . \mathrm{H}_{2} \mathrm{O}$ $\left(113.67(3)^{\circ}\right) .^{41}$ The O-P-O bond angles of $96.76(5)^{\circ}$ and $95.7(2)^{\circ}$ in compounds $\mathbf{1}$ and $\mathbf{2}$ are similar to $\left[\mathrm{Et}_{3} \mathrm{NH}\right]^{+}\left[\left(2-\mathrm{MeC}_{6} \mathrm{H}_{4} \mathrm{O}\right)_{2} \mathrm{PS}_{2}\right]^{-}\left(97.07(8)^{\circ}\right)^{42}$ but slightly larger in the compounds $\left[\mathrm{Et}_{3} \mathrm{NH}\right]^{+}\left[\mathrm{CH}_{2}\{6-\mathrm{t}-\right.$ $\left.\left.\mathrm{Bu}-4-\mathrm{Me}-\mathrm{C}_{6} \mathrm{H}_{4} \mathrm{O}\right\}_{2} \mathrm{P}(\mathrm{S})(\mathrm{S})\right]^{-} \quad\left(103.5(4)^{\circ}\right),{ }^{39} \quad \mathrm{HS}_{2} \mathrm{POC}$ $\mathrm{Me}_{2} \mathrm{CMe}_{2} \mathrm{O} \quad\left(105.1(1)^{\circ}\right),{ }^{40} \quad \mathrm{~K}_{2}^{+}\left[(\mathrm{MeO}) \mathrm{OPS}_{2}\right]^{-} \cdot \mathrm{H}_{2} \mathrm{O}$ $\left(100.93(7)^{\circ}\right),{ }^{41}$ and $\left[\mathrm{Et}_{3} \mathrm{NH}\right]^{+}\left[\left(\mathrm{OCH}_{2} \mathrm{CMe}_{2} \mathrm{CH}_{2} \mathrm{O}\right)_{2} \mathrm{PS}_{2}\right]^{-}$ $\left(101.4(2)^{\circ}\right){ }^{39}$

The $\mathrm{N}-\mathrm{H}$ bond length in compounds $\mathbf{1}$ and $\mathbf{2}$ are 0.881(13) and 0.87(5) $\AA$, which are in reasonable agreement with the values found in compound 3 (0.94(4) $\AA)^{25}$ (table 3). P1-S1 and P1-S2 bond lengths for compound 1 are 1.9413(5) and 1.9779(5) $\AA$ while for compound 2, bond lengths are 1.9440 (18) and 1.9626 (18) $\AA$. These bond lengths are comparable with compound 3 (1.9389(12) and 1.9586(12) $\AA$ ). ${ }^{25}$ The S1-P1$\mathrm{S} 2$ bond angle in compounds $\mathbf{1}$ and $\mathbf{2}$ is $118.46(2)^{\circ}$ and $117.94(9)^{\circ}$ which are akin to the value found in compound $3\left(119.31(6)^{\circ}\right){ }^{25}$

\subsection{Infrared spectra}

Vibrational spectroscopy has been widely used for structural characterization of molecular systems by DFT calculations. It is found that the calculated frequencies by Gaussian 03 are closer to the experimental values. Experimental and calculated vibration frequencies along with corresponding vibrational assignments are given in table 5. IR spectra have shown a broad absorption for $[v \mathrm{~N}-\mathrm{H}]$ vibrations in the region $3431-3397 \mathrm{~cm}^{-1}$ in the compound 1-3 and the theoretical data for $[v \mathrm{~N}-\mathrm{H}]$ vibration is in the region $3651-3452 \mathrm{~cm}^{-1}$. In the compounds $\mathbf{1}-\mathbf{3}[v(\mathrm{P})-\mathrm{O}-\mathrm{C}]$ and $[v \mathrm{P}-\mathrm{O}-(\mathrm{C})]$ stretching vibrations were found in the region $1196-1141 \mathrm{~cm}^{-1}$ and $870-843 \mathrm{~cm}^{-1}$, respectively, which are in agreement with the results computed as $1196-1133 \mathrm{~cm}^{-1}$ and $895-845 \mathrm{~cm}^{-1}$ (for DFT). The observed bands in the region $688-672 \mathrm{~cm}^{-1}$ and $586-574 \mathrm{~cm}^{-1}$ for $[v \mathrm{P}=\mathrm{S}]$ and $[v \mathrm{P}-\mathrm{S}]$ match with the corresponding theoretical data and are found as $684-667 \mathrm{~cm}^{-1}$ and $575-542 \mathrm{~cm}^{-1}$. In this study, only characteristic stretching vibration bands were identified which are in good agreement with the related experimental study previously reported..$^{25}$

\subsection{Computational discussion}

It would be appropriate here to correlate the structural parameters obtained from the crystal structure studies with computational data. Figure 2 shows the optimized molecular structures for compounds 1-3 for which comparison of the selected bond lengths and bond angles

Table 5. Selected experimental and calculated IR vibrational frequencies $\left(\mathrm{cm}^{-1}\right)$ for compounds 1-3.

\begin{tabular}{lcccccccc}
\hline & \multicolumn{2}{c}{ Compound 1 } & & \multicolumn{2}{c}{ Compound 2 } & & \multicolumn{2}{c}{ Compound 3 } \\
\cline { 2 - 5 } \cline { 7 - 8 } \cline { 7 - 8 } Assignment & Experimental & Theoretical & & Experimental & Theoretical & & Experimental & Theoretical \\
\hline$[\nu \mathrm{N}-\mathrm{H}]$ & $3397 \mathrm{~b}$ & 3651 & & $3399 \mathrm{~b}$ & 3452 & & $3431 \mathrm{~b}$ & 3488 \\
{$[\nu(\mathrm{P})-\mathrm{O}-\mathrm{C}]$} & $1196 \mathrm{~s}$ & 1196 & & $1148 \mathrm{~s}$ & 1154 & & $1141 \mathrm{~s}$ & 1133 \\
{$[\nu \mathrm{P}-\mathrm{O}-(\mathrm{C})]$} & $870 \mathrm{~s}$ & 895 & & $856 \mathrm{~s}$ & 848 & & $843 \mathrm{~s}$ & 851 \\
{$[\nu \mathrm{P}=\mathrm{S}]$} & $673 \mathrm{~s}$ & 684 & & $672 \mathrm{~s}$ & 686 & & $688 \mathrm{~s}$ & 667 \\
{$[\nu \mathrm{P}-\mathrm{S}]$} & $586 \mathrm{~m}$ & 575 & & $574 \mathrm{~m}$ & 542 & & $578 \mathrm{~m}$ & 570 \\
\hline
\end{tabular}




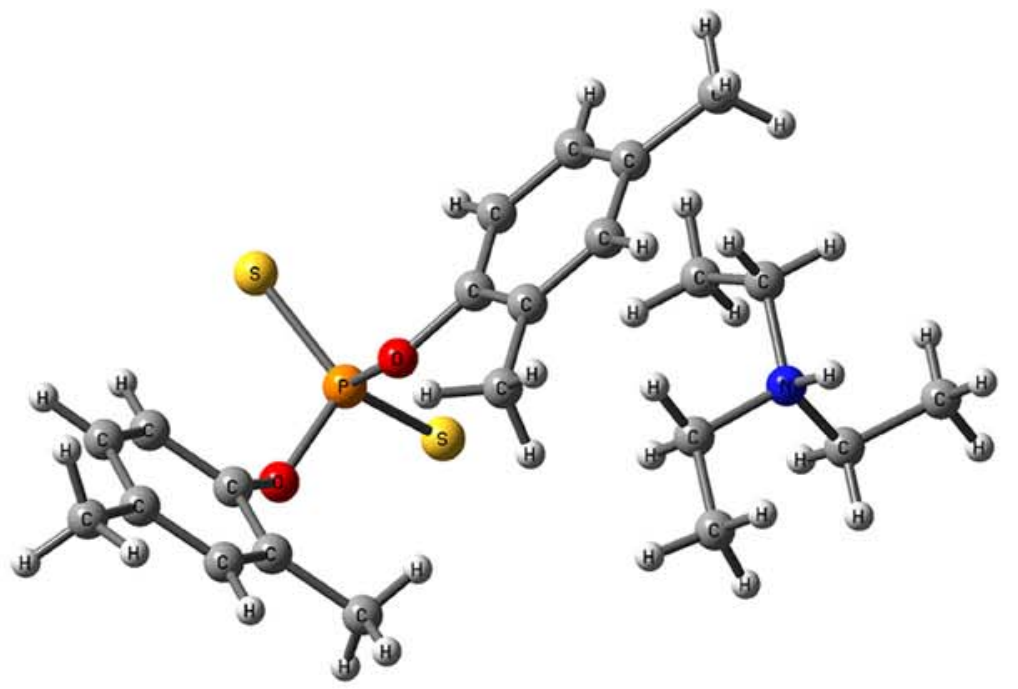

(a)

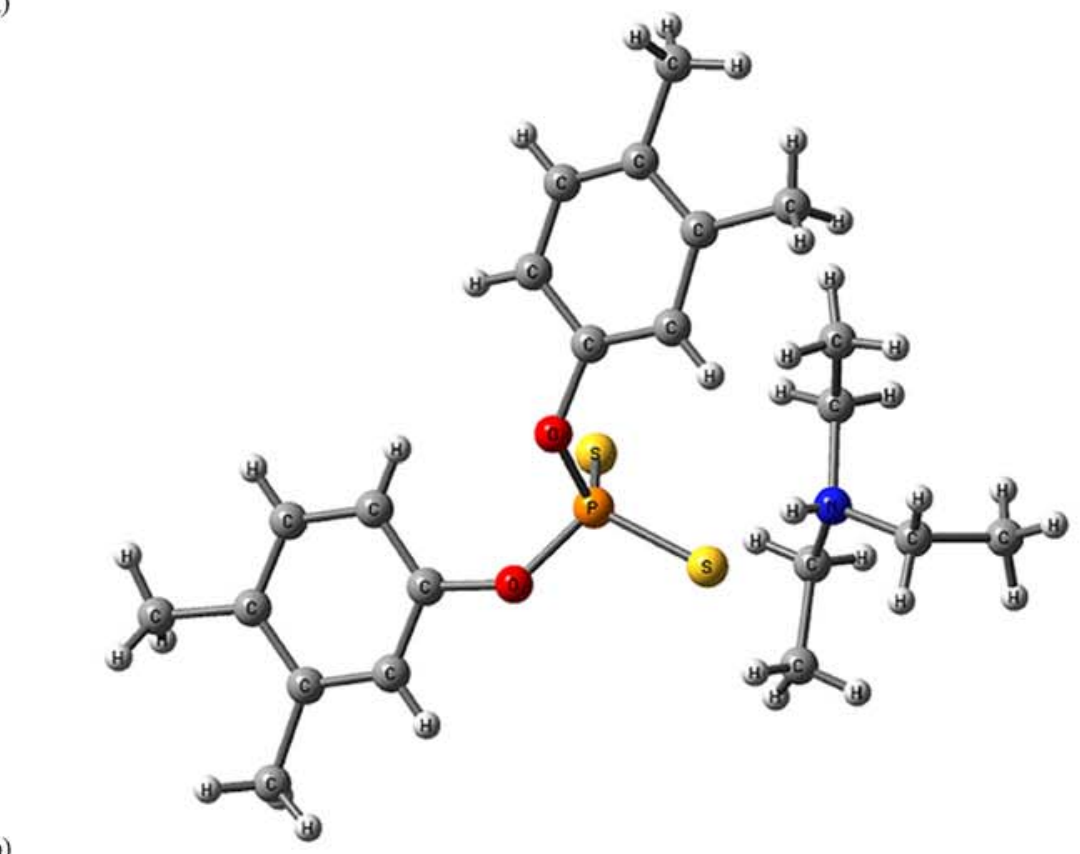

(b)

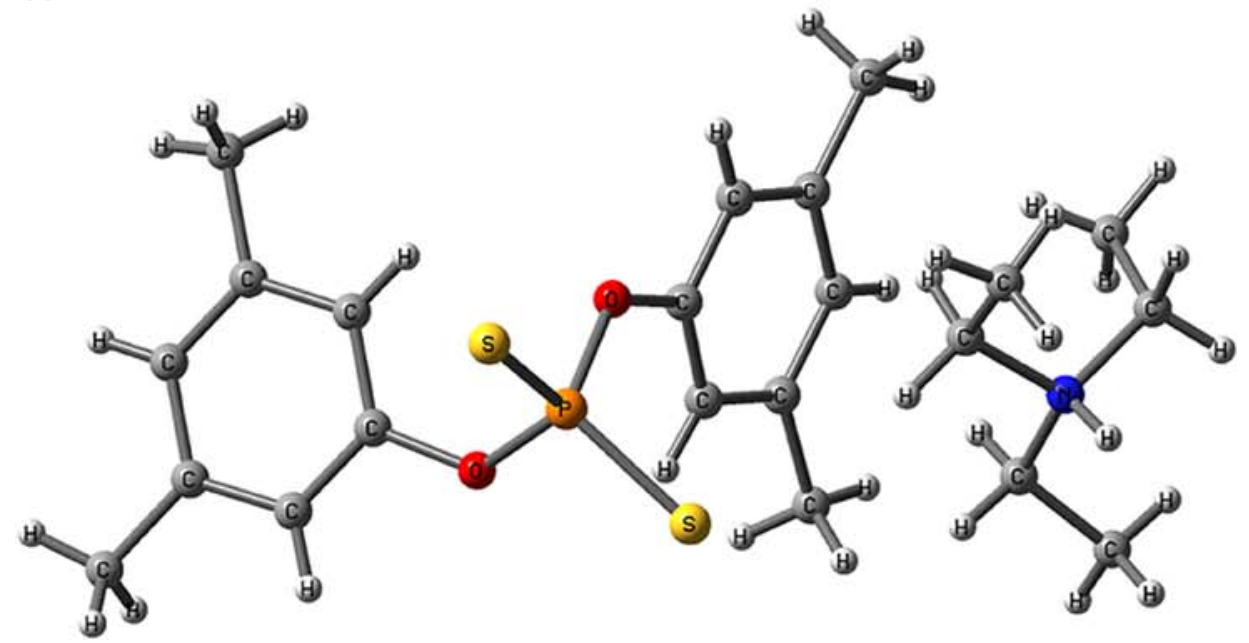

(c)

Figure 2. Optimized structure of, (a) $\left[\left\{\left(2,4-\mathrm{CH}_{3}\right)_{2} \mathrm{C}_{6} \mathrm{H}_{3} \mathrm{O}\right\}{ }_{2} \mathrm{PS}_{2} \mathrm{HNEt}_{3}\right]$ (1); (b) $\left[\left\{\left(3,4-\mathrm{CH}_{3}\right)_{2} \mathrm{C}_{6} \mathrm{H}_{3} \mathrm{O}\right\}_{2} \mathrm{PS}_{2} \mathrm{HNEt}_{3}\right](\mathbf{2})$; (c) $\left[\left\{\left(3,5-\mathrm{CH}_{3}\right)_{2} \mathrm{C}_{6} \mathrm{H}_{3} \mathrm{O}\right\}_{2} \mathrm{PS}_{2} \mathrm{HNEt}_{3}\right](3)$. 
Table 6. Selected experimental and calculated bond lengths

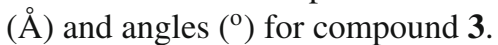

\begin{tabular}{llll}
\hline $\begin{array}{l}\text { Bond lengths/ } \\
\text { Bond angles }\end{array}$ & Experimental & Calculated & Deviation \\
\hline $\mathrm{N} 1-\mathrm{H} 1$ & $0.94(4)$ & 0.94 & 0 \\
$\mathrm{P} 1-\mathrm{O} 1$ & $1.610(2)$ & 1.622 & -0.012 \\
$\mathrm{P} 1-\mathrm{O} 2$ & $1.622(2)$ & 1.610 & 0.012 \\
$\mathrm{P} 1-\mathrm{S} 1$ & $1.9389(12)$ & 1.939 & 0.001 \\
$\mathrm{P} 1-\mathrm{S} 2$ & $1.9586(12)$ & 1.958 & 0 \\
$\mathrm{O} 1-\mathrm{P} 1-\mathrm{O} 2$ & $102.33(12)$ & 102.33 & 0 \\
$\mathrm{O} 1-\mathrm{P} 1-\mathrm{S} 1$ & $112.57(10)$ & 111.07 & 1.5 \\
$\mathrm{O} 2-\mathrm{P} 1-\mathrm{S} 1$ & $105.96(9)$ & 104.39 & 1.57 \\
$\mathrm{O} 1-\mathrm{P} 1-\mathrm{S} 2$ & $104.41(9)$ & 105.96 & -1.55 \\
$\mathrm{O} 2-\mathrm{P} 1-\mathrm{S} 2$ & $111.06(9)$ & 112.57 & 1.51 \\
$\mathrm{~S} 1-\mathrm{P} 1-\mathrm{S} 2$ & $119.31(6)$ & 119.31 & 0 \\
\hline
\end{tabular}

are given in the tables 2, 3 and 6. Interestingly, all of the geometric structures were identified and after optimization they tend to reorganise close to the experimental structures. The optimized geometry analysis reveals that the observed and calculated coordination number and the molecular geometry are also in agreement. The computed bond lengths and bond angles help us to understand the molecular structure of the compounds. The experimental values for $\mathrm{N}-\mathrm{H}$ bond lengths for compounds 1-3 (0.87(5)-0.94(4) ̊) are comparable with computed bond lengths $(0.717-0.950 \AA)$. The experimental P1-S1 and P1-S2 bond lengths (1.9389(12)$1.9440(18) \AA)$ and (1.9586(12)-1.9779(15) $\AA$ are as good as the theoretical values (1.939-2.014 and 1.944$1.989 \AA$ ). The bond angle S1-P-S2 is measured as $117.94(9)-119.31(6)^{\circ}$ and it is calculated as $117.95^{\circ}$ $119.31^{\circ}$ by using DFT.

\subsection{HOMO-LUMO analyses}

The frontier molecular orbital energies have been calculated with B3LYP/6-31G*/LANL2DZ level of theory in the gaseous phase. The HOMO and LUMO are main orbitals that take part in chemical reactions. It has been found that the HOMO is largely distributed over the oxygen and sulfur atoms of anionic dithiophosphates moiety in compounds $\mathbf{1 - 3}$. LUMO, the lowest unoccupied molecular orbital, is distributed over the triethylammonium moiety in compounds $\mathbf{1}$ and $\mathbf{3}$ while it is distributed over the phenyl ring of dithiophosphate in compound 2 (figure 3 ). The energy gap between the HOMO and the LUMO is a critical parameter in determining molecular electrical transport properties and electron conductivity. The energy gap values in the compounds $\mathbf{1 - 3}$ are $3.952 \mathrm{eV}, 4.575 \mathrm{eV}$ and $4.0197 \mathrm{eV}$, respectively. Further, HOMO and LUMO

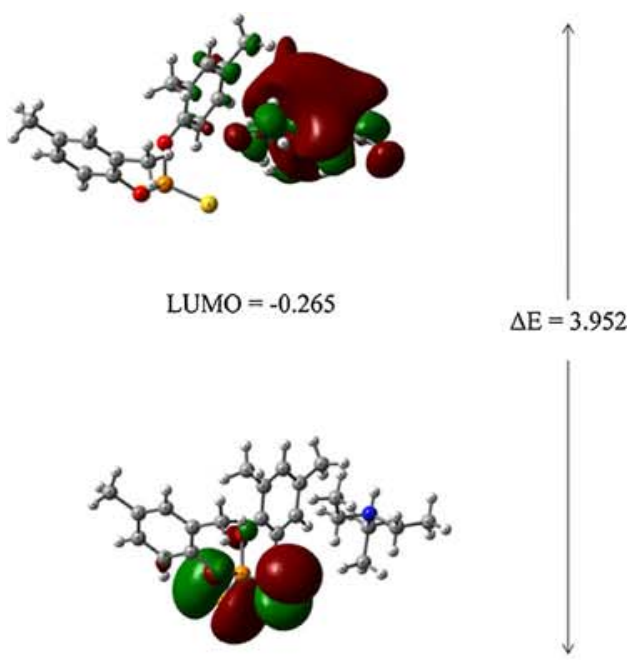

(a) $\mathrm{HOMO}=-4.217$
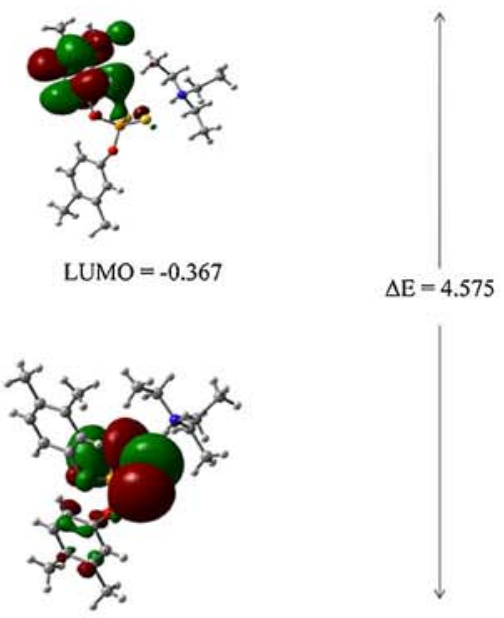

(b)

$$
\mathrm{HOMO}=-4.942
$$

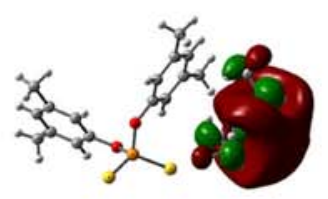

LUMO $=-0.0043$
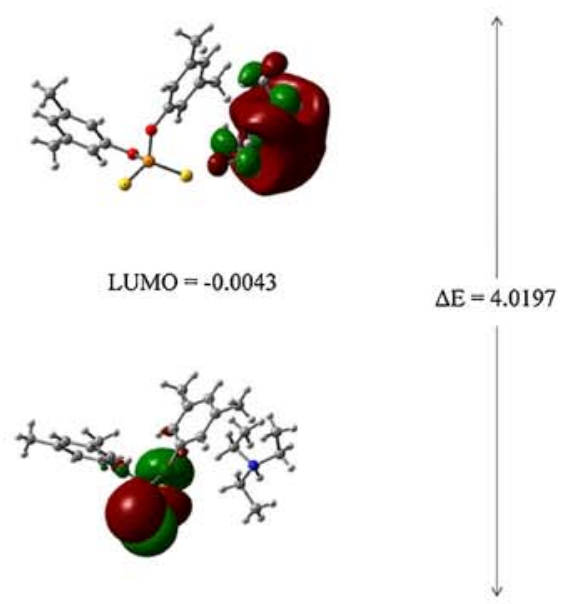

(c)

$\mathrm{HOMO}=-4.024$

Figure 3. Frontier molecular orbital surfaces and energy gap for, (a) $\left[\left\{\left(2,4-\mathrm{CH}_{3}\right)_{2} \mathrm{C}_{6} \mathrm{H}_{3} \mathrm{O}\right\}_{2} \mathrm{PS}_{2} \mathrm{HNEt}_{3}\right]$ (1); (b) $[\{(3,4-$ $\left.\left.\left.\mathrm{CH}_{3}\right)_{2} \mathrm{C}_{6} \mathrm{H}_{3} \mathrm{O}\right\}{ }_{2} \mathrm{PS}_{2} \mathrm{HNEt}_{3}\right]\left(\right.$ (2); (c) $\left[\left\{\left(3,5-\mathrm{CH}_{3}\right)_{2} \mathrm{C}_{6} \mathrm{H}_{3} \mathrm{O}\right\}_{2}\right.$ $\left.\mathrm{PS}_{2} \mathrm{HNEt}_{3}\right]$. 
energy gap also explains the eventual charge transfer interactions taking place within the molecule. ${ }^{43}$

\section{Conclusions}

In the present work, DFT studies of the structure in terms of geometries, bond lengths and bond angles as well as spectroscopic properties (vibrational and HOMO-LUMO) of aromatic dithiophosphates are reported and compared with experimental results for the first time. X-ray analysis reveals that tetrahedral coordination around the phosphorus atom is formed by two $\mathrm{S}$ and two $\mathrm{O}$ atoms. The structure is stabilized by cation-anion $\mathrm{N}-\mathrm{H} \cdots \mathrm{S}$ hydrogen bond interactions. The theoretical, experimental and vibrational structural parameters are in qualitative agreement with crystal and spectroscopic data. The experimental and theoretical bond lengths and angles are in good agreement with each other with small deviations. The accuracy of results also predicts that the DFT studies performed at B3LYP/LANL2DZ level is the appropriate quantum chemical method for reproducing the experimental results for these compounds. The small discrepancies in geometric and vibrational parameters are attributable to the packing interactions within the lattice which are not modelled in computational study. HOMO-LUMO gaps suggest that the charge transfer interactions occur within these complexes.

\section{Supplementary Information (SI)}

CCDC 1414793-1414794 contain the supplementary crystallographic data for compounds $\mathbf{1}$ and $\mathbf{2}$. These data can be obtained free of charge via http://www. ccdc.cam.ac.uk/conts/retrieving.html, or from the Cambridge Crystallographic Data Centre, 12 Union Road, Cambridge CB2 1EZ, UK; fax: (+44) 1223-336-033; or e-mail: deposit@ccdc.cam.ac.uk.

\section{Acknowledgements}

RK acknowledges the DST for the single crystal X-ray diffractometer as a National Facility under Project No. SR/S2/CMP-47/2003.

\section{References}

1. Cotero-Villegas A M, Toscano R A, Munoz-Hernandez M, Lopez-Cardoso M, Garcia Y, Garcia P and Ceaolivares R 2005 J. Organomet. Chem. 6902872

2. Jain P U, Paul H, Munshi P, Walawalkar M G and Lahiri G K 2001 Polyhedron 20245
3. Szucova L, Travneck Z and Marek J 2003 Polyhedron 221341

4. Chauhan H P S 1998 Coord. Chem. Rev. 1731

5. Sharma C S and Nagar P N 2006 Phosphorus, Sulfur Silicon Relat. Elem. 181453

6. Chordia L and Chaturvedi A 2011 Main Group Met. Chem. 31319

7. Chander R, Kalsotra B L and Pandey S K 2004 Ind. J. Chem. 43A 1134

8. Tripathi U N 2000 Phosphorus, Sulfur Silicon Relat. Elem. 15947

9. Shetty P S and Fernando Q $1970 \mathrm{~J}$. Am. Chem. Soc. 92 3964

10. Molloy K C, Hossain M B, Helm D V, Zuckerman J J and Haiduc I 1979 Inorg. Chem. 183507

11. Nicholls M A, Bancroft G M, Norton P R, Kasrai M, Stasio G D, Frazer B H and Wiese L M 2004 Tribol. Lett. 17245

12. Jianqiang $\mathrm{H}$, Huanqin $\mathrm{Z}$, Li W, Xianyong W, Feng $\mathrm{J}$ and Zhiming Z 2005 Wear 259519

13. Kubo H 1965 Agric. Biol. Chem. 2943

14. Kumar A, Sharma K R and Pandey S K 2007 Phosphorus, Sulfur Silicon Relat. Elem. 1821023

15. Drake J E, Macdonald C L B, Kumar A, Pandey S K and Ratnani R 2005 J. Chem. Cryst. 35447

16. Kumar A, Kumar D and Pandey S K 2007 Synth. React. Inorg. Met.-Org. Nano-Met. Chem. 37697

17. Sharma K R, Kumar D, Kumar A and Pandey S K 2008 J. Coord. Chem. 611811

18. Gupta B, Magotra S and Pandey S K 2008 Monatsh. Chem. 139747

19. Gupta B, Kumar K and Pandey S K 2009 Synth. React. Inorg. Met.-Org. Nano Met. Chem. 39559

20. Kour S, Gupta B, Chander R and Pandey S K 2009 Main Group Met. Chem. 32195

21. Sharma S, Magotra S and Pandey S K 2009 Phosphorus, Sulfur Silicon Relat. Elem. 1842140

22. Kumar A, Kumar K and Pandey S K 2009 Polish J. Chem. 832097

23. Perez-Garcia F, Alvarado-Rodriguez J G, GalanVidal C A, Paez-Hernandez M E, Andrade-Lopez N and Moreno-Esparza R 2010 Struct. Chem. 21191

24. Bajia S C 2011 Synth. React. Inorg. Met.-Org. Nano Met. Chem. 41746

25. Khajuria R, Kumar S, Kour G, Anthal S, Gupta V K, Kant R and Pandey S K 2014 J. Coord. Chem. 672925

26. Kumar S, Khajuria R, Gupta V K, Kant R and Pandey S K 2014 Polyhedron 72140

27. Kart H H, Özdemir Kart S, Karakus M and Kurt M 2014 Spectrochim. Acta, Part A 129421

28. Billesa F, Holmgren A and Mikosch H 2010 Vib. Spectrosc. $\mathbf{5 3} 296$

29. SADABS-2008/1 - Bruker AXS area detector scaling and absorption correction

30. Altomare A, Cascarano G, Giacovazzo C and Guagliardi A 1993 J. Appl. Crystallogr. 26343

31. Sheldrick G M 2008 Acta Crystallogr. A64 112

32. Farrugia L J 1999 J. Appl. Crystallogr. 32837

33. Nardelli M 1995 J. Appl. Crystallogr. 28659

34. Spek A L 2009 Acta Crystallogr. D65 148

35. Brandenburg K 1998 DIAMOND, Version 2.1 (Crystal Impact GbR: Bonn, Germany) 
36. Frisch M J, Trucks G W, Schlegel H B, Scuseria G E, Robb M A, Cheeseman J R, Zakrzewski V G, Montgomery J A, Stratmann R E, Burant J C, Dapprich S J M, Millam Daniels A D, Kudin K N, Strain M C, Farkas O, Tomasi J, Barone V, Cossi M, Cammi R, Mennucci B, Pomelli C, Adamo C, Clifford S, Ochterski J, Petersson G A, Ayala P Y, Cui Q, Monocular K, Malick D K, Rabuck A D, Raghavachari K, Foresman J B, Kieslowski J, Ortiz J V, Baboul A G, Stefano B B, Liu G, Liashenko A, Piskorz P, Komaromi I, Gomperts R, Martin R L, Fox D J, Keith T, Al-Laham M A, Peng C Y, Nanayakkara A, Challacombe M, Gill P M W, John-son B, Chen W, Wong M W, Andres J L, Gonzalez C, Head-Gordon M, Replogle E S and Pople J A 2004
Gaussian 03, Revision B.04 (Gaussian, Inc.: Wallingford CT)

37. Lee C, Yang W and Parr R G 1988 Phys. Rev. B37 785

38. Kumar R, Obrai S, Kaur A and Hundal M S 2015 J. Coord. Chem. 682130

39. Kumaraswamy K C, Kumaraswamy S, Raja S and Kumar K S 2001 J. Chem. Crystallogr. 3151

40. Drake J E, Khasrou L N, Mislanker A G and Ratnani R 2000 Polyhedron 19407

41. Gupta M C 2004 Ph.D Thesis (University of Rajasthan, Jaipur, India)

42. Drake J E, Macdonald C L B, Kumar A, Pandey S K and Ratnani R 2005 J. Chem. Crystallogr. 35447

43. Fukui K 1982 Science $\mathbf{2 1 8} 747$ 